\title{
Autonomic symptoms in idiopathic Parkinson's disease
}

\author{
Parkinson hastalığında otonomik semptomların varlı̆̆ının araştırılması \\ Semra Arı*, Fatma Candan, Nihal Işıı, Özgür Öztop, İlknur Aydın Cantürk, \\ Özge Arıcı Düz
}

Department of Neurology (S. Arı, MD, F. Candan, MD, Assoc. Prof. N. Işık, MD, Ö. Öztop, MD, İ. A. Cantürk, MD, Ö. A. Düz, MD), Medeniyet University School of Medicine Göztepe Education and Research Hospital, TR-34722 İstanbul

\begin{abstract}
Aim. Autonomic symptoms (AS) are one of the major causes affecting quality of life in Parkinson's disease (PD) patients and contribute to the disease burden. Our aim is to investigate the occurence of AS and to evaluate the relation between AS and the demographic and clinical features of PD patients. Method. In this study 66 idiopathic PD patients (47 men) were evaluated for the presence of AS during the last month with the SCOPA-AUT (Scales for Outcomes in Parkinson's Disease; SCOPA) questionnaire, which consists of 23 items in six domains: gastrointestinal (7), urinary (6), cardiovascular (3), thermoregulatory (4), pupillomotor (1), and sexual (2). The maximum score is 69 , with a score range per item from 0 (never experiencing the symptom) to 3 (often experiencing the symptom). Associations between AS and duration of disease, age onset of disease, treatment and Hoehn \&Yahr stage scores were also studied. Results. The mean (SD) age was 67.1 (9.5), disease duration 5.1 (3.9), age onset of disease 59 (10.9) years and Hoehn \&Yahr median stage 1.9 (0.75, range I-IV). The presence of AS in all patients was observed. Mean SCOPA-AUT score was 15.6 (4-32). Total SCOPA-AUT scores were found significantly associated with duration of disease and Hoehn\&Yahr stages $(p<0.05)$, in contrast to age and gender. The most leading AS were in the gastorintestinal domain which was associated with the disease severity and duration also $(\mathrm{p}<0.05)$. Conclusion. AS were present in all patients even at the disease onset and early stages and increased with the disease severity and duration. For a better quality of life of the patient, it' s important to evaluate the presence of AS and initiate the appropriate treatment.
\end{abstract}

Keywords: Parkinson's Disease, SCOPA-AUT, otonomic symptoms

\section{Özet}

Amaç. Otonomik semptomlar, Parkinson hastalığında hayat kalitesini düşüren ve hastalık yükünde etkisi olan temel nedenlerden bir tanesidir. Bu çalışmanın amacı, Parkinson hastalarında OS'ların varlığının araştırılması ve bu semptomlar ile hastalığın demografik ve klinik özellikleri arasındaki ilişkinin incelenmesidir. Yöntem. Çalışmaya 66 İdiopatik Parkinson hastası (47E) dahil edildi. Hastalar, OS'ları kapsamlı olarak tarayan 23 adet sorunun 6 ana alanda sorgulandığı bir anket (SKOPA-AUT Questionary) ile değerlendirildi. Bu anket ile gastrointestinal fonksiyonlar (7 soru), Üriner fonnksiyonlar (6 soru), kardiovasküler (3 soru), termoregulatuar (4 soru), pupillomotor (1 soru) ve seksüel fonksiyonlar (2 soru erkek, 2 soru kadın için) sorgulandı. Semptomların son 1 ay içindeki varlığ 1 göz önünde bulunduruldu. Toplam skor 69 olup her soru 0 dan (hiç semptom yok) 3'e (sıklıkla semtom var) kadar skorlandı. Sempomlar ile hastaların yaşı, cinsiyeti, hastalık başlangıç yaşı, hastalık süresi ve Hoenh\&Yahr (H\&Y) evresi ile arasındaki ilişki incelendi. Bulgular. Hastaların ortalama yaşı 67,1 (9,5), süresi 5,1 $(3,9)$, hastalık başlangıç yaşı $59(10,9)$ yıl ve ortalama Hoehn \&Yahr evresi 1,9 (0,75; I-IV) idi. Total SKOPA-AUT skoru 15,9 idi. Total skor ile yaş ve cinsiyet arasında bir ilişki olmayıp ( $p>0,05)$, hastalık süresi ve evresi arasında anlamlı bir ilişki bulundu $(\mathrm{p}<0,05)$. OS'ların en fazla gözlendiği alan gastrointestinal sistem olup hastalık süresi ve şiddeti ile de ilişkili olduğu saptandı. Sonuç. PH'nın erken evrelerinde ve hatta hastalığın başlangıç dönemlerinde dahi OS'lar görülebilmekte ve hastalık şiddeti ve süresi ile de artış göstermektedir. Parkinson hastalarında OS'lara yönelik ileri tetkik ve tedavinin planlanması, hastaların hayat kalitesini arttıracaktır.

Anahtar sözcükler: Parkinson hastalığ 
Geliş tarihi/Received: September 01, 2014; Kabul tarihi/Accepted: July 14, 2014

\section{*Corresponding author:}

Dr. Semra Arı, Nöroloji Anabilim Dalı, Medeniyet Üniversitesi Göztepe Eğitim ve Araştırma Hastanesi, TR-34722 İstanbul. E-mail: ranasemraari@ hotmail.com

\section{Introduction}

Autonomic dysfunction in patients with Parkinson's disease has been recognized since the original description of the disease by James Parkinson in 1987 [1]. Autonomic symptoms (AS) occur in almost most patients with Parkinson's disease (PD) patients at any stage of their disease and contribute to the disease burden [2, 3]. In contrast to autonomic dysregulation in pure autonomic failure and multisystem athrophy, they are less severe. Nevertheless, AS are one of the major causes affecting quality of life and daily functioning in (PD) patients. Symptoms of dysautonomia are variable, include gastrointestinal symptoms, urogenital, cardiovascular, thermoregulatuar, pupillomotor, and sexual. Gastrointestinal, cardiovascular and urogenital autonomic dysfunctions are prominent.

In PD patients, both the central and peripheral autonomic nervous systems can be affected supported by pathological and physiological studies [6, 7]. Pathological abnormalities have been reported in hypothalamus, brainstem, intermediolateral cell column, autonomic ganglia and myenteric plexus [6-8]. Parasympathetic nervous system disfunction may selectively be present early in the course of the disease [9]. The reported prevalence of autonomic dysfunction varies between $14 \%$ and $80 \%[4,5]$. The confounding results between the studies are most likely explained by both the use of different assessment methods or by the atypical patient groups. There have been a growing interest in evaluating motor and non motor symptoms and therapeutic options on PD, but no such instrument existed. Therefore, a valid and a reliable questionnarie that focused on the AS in PD (SCOPA_AUT) was recently developed [3].

In this study, we aimed to invastigate the relationship between the existance of AS and demographic and clinical features of PD patients.

\section{Material and methods}

In this study 66 nondemented idiopathic PD patients (47 men) from the Movement disorders outpatient clinic of Medeniyet University Neurology Department were evaluated. All patients fullilled the United Kingdom PD Society Brain Bank criteria for idiopathic PD. In all patients duration and age onset of disease, Hoehn\&Yahr stages and UPDRS scores were determined. The patients were classified into 3 clinicaly subgroups as; akinetic-rijid type, tremor-dominat type and mix type. To explore the influence of disease severity, patients were classified in groups based on $\mathrm{H} \& \mathrm{Y}$ stages in mild $\mathrm{PD}$ (H\&Y 1 or 2), moderate PD (H\&Y 3) or severe PD (H\&Y 4 or 5).

All patients were evaluated for the presence of AS during the last month with the SCOPA-AUT, (spesific clinical assessment tool for autonomic disturbances; Visser M, Marinus $\mathbf{J}$ et al. [3] a questionnaire, which consists of 23 items in six domains: gastrointestinal [7], urinary [6], cardiovascular [3], thermoregulatory [4], pupillomotor [1], and sexual ( 2 items for men and 2 items for women). The maximum score is 69 , with a score range per item from 0 (never experiencing the symptom) to 3 (often experiencing the symptom). The questionnaire administered by the phycians on 'on' period with the aid of caregivers where necessary. The study was approved by the local Ethical Committee. An informed consent was taken from all patients. 


\section{Statistical analysis}

All data was analyzed by NCSS 2007\&PASS 2008 Statistical Software (Utah, USA). The association between continous variables was tested through Student $t$ test (parametric data), Mann Whitney U test and Kruskall Wallis test (non parametric data). Relationship between parameters were tested with Pearson and Spearman's correlation analysis. Chi square test was perfored to compare qualitative data. The $95 \%$ confidence interval and the level of significance of 0.05 were used.

\section{Results}

The mean age was $64.1 \pm 9.5$ years, disease duration $5.1 \pm 3.9$, age onset of disease $59 \pm$ 10.9 years and Hoehn \&Yahr median stage 1.9 (0.75, range I-IV) (Table 1). AS was observed in all patients. Mean SCOPA-AUT score was 15.6 (4-32) (Table 1, 2). Total SCOPA-AUT scores were found significantly associated with duration of disease, H\&Y and UPDRS stages (Figure 1,2) $(\mathrm{p}<0.05)$, in contrast to age and gender. The most leading AS were in the urinary and in the gastorintestinal domain whereas only the gastrointestinal domain was associated with the disease severity and duration $(p<0.05)$ (Table 1,2). However, the least frequent AS were in the pupillomotor and cardivascular systems, respectively. In addition to this, the frequency of cardiovascular system was significantly higher with longer disease duration. Besides, when the patients with mild $\mathrm{H} \& \mathrm{Y}$ compared with the patients with moderate H\&Y, patients with moderate PD experienced significantly more GIS, urinary and CVS problems with total score. To obtain insight into the most relevant AS in PD, items which were marked by patients with scores $\geq 2$ were identified. These items were constipation (34.9\%), straining for defacation (39.4\%), urinating in night $(56.1 \%)$ and frequency of urinating (30.3\%). No siginificant differences were found between the clinical subtypes of the patients.

Table 1. Relation between the total SCOPA_AUT score and demographic and clinical features.

\begin{tabular}{|c|c|c|c|c|c|}
\hline & $\mathbf{n}$ & $\%$ & Min-max & Mean \pm SD & $\mathbf{p}$ \\
\hline Total SCOPA-AUT score & & $4-32$ & $15.06 \pm 7.08$ & & Total SCOPA-AUT score \\
\hline Gender & 66 & & & & \\
\hline Male & 47 & 71.2 & & & $0.659^{\wedge}$ \\
\hline Female & 19 & 2.28 & & & \\
\hline Age & & & $40-85$ & $64.07 \pm 9.55$ & 0.698 \\
\hline Age onset of disease & & $33-81$ & $59.00 \pm 10.98$ & 0.253 & \\
\hline Duration of disease & & $0-16$ & $5.07 \pm 3.85$ & $0.024 "$ & \\
\hline \multicolumn{6}{|l|}{ Clinical subtypes } \\
\hline $\mathrm{AK}$ & 23 & 34.8 & & & \\
\hline TD & 22 & 33.3 & & & $\bullet \bullet 0.191$ \\
\hline MIX & 21 & 31.8 & & & \\
\hline $\mathrm{H} \& \mathrm{Y}$ & & & $1-4$ & $1.90 \pm 0.75$ & $0.034^{\prime}$ \\
\hline UPDRS & & & $6-64$ & $23.9 \pm 12.9$ & $0.038 "$ \\
\hline
\end{tabular}

Table 2. Relation between the SCOPA-AUT scores with clinical features.

\begin{tabular}{llllll}
\hline & & & Duration & H\&Y & \\
\hline & min-max & mean \pm SD & r & p & min-max \\
\hline Total score & $4-32$ & $15.06 \pm 7.08$ & 0.278 & $0.024^{*}$ & $4-32$ \\
Gastrointestinal System & $0-13$ & $4.36 \pm 3.13$ & 0.302 & $0.014^{*}$ & $0-13$ \\
Urinary System & $1-15$ & $5.96 \pm 3.81$ & 0.146 & 0.242 & $1-15$ \\
Cardiovascular System & $0-4$ & $0.93 \pm 1.06$ & 0.266 & $0.031^{*}$ & $0-4$ \\
Thermoregulatory System & $0-8$ & $2.15 \pm 2.06$ & 0.134 & 0.283 & $0-8$ \\
Pupillomotor System & $0-2$ & $0.36 \pm 0.54$ & 0.019 & 0.878 & $0-2$ \\
Sexual System & $0-6$ & $1.91 \pm 2.07$ & 0.06 & 0.668 & $0-6$ \\
\hline r: Spearman's korelasyon, $: \mathrm{p}<0.05, * *: \mathrm{p}<0.01$ & & & \\
\hline
\end{tabular}


Table 3. Items scores.

\begin{tabular}{|c|c|c|c|c|c|}
\hline \multirow[t]{3}{*}{ Item } & \multicolumn{5}{|l|}{ Scopa aut } \\
\hline & Never 1 & Sometimes 2 & Regularly 3 & Often 4 & Total \\
\hline & $\mathrm{n}(\%)$ & $\mathrm{n}(\%)$ & $\mathrm{n}(\%)$ & $\mathrm{n}(\%)$ & $\mathrm{n}(\%)$ \\
\hline \multicolumn{6}{|l|}{ Gastrointestinal domain } \\
\hline Swallowing/choking & $45(\% 68.2)$ & $21(\% 31.8)$ & - & - & $66(\% 100.0)$ \\
\hline Sialorrhea & $32(\% 48.5)$ & $25(\% 37.9)$ & $4(\% 6.1)$ & $5(\% 7.6)$ & $66(\% 100.0)$ \\
\hline Dysphagia & $43(\% 65.2)$ & $22(\% 33.3)$ & - & $1(\% 1.5)$ & $66(\% 100.0)$ \\
\hline Early abdominal fullness & $47(\% 71.2)$ & $12(\% 18.2)$ & $6(\% 9.1)$ & $1(\% 1.5)$ & $66(\% 100.0)$ \\
\hline Constipation & $22(\% 33.3)$ & $21(\% 31.8)$ & $13(\% 19.7)$ & $10(\% 15.2)$ & $66(\% 100.0)$ \\
\hline Straining for defecation & $21(\% 31.8)$ & $19(\% 28.8)$ & $14(\% 21.2)$ & $12(\% 18.2)$ & $66(\% 100.0)$ \\
\hline Fecal incontinence & $59(\% 89.4)$ & $7(\% 10.6)$ & - & - & $66(\% 100.0)$ \\
\hline \multicolumn{6}{|l|}{ Urinary domain } \\
\hline Urinary urgency & $27(\% 40.9)$ & $26(\% 39.4)$ & $6(\% 9.1)$ & $7(\% 10.6)$ & $66(\% 100.0)$ \\
\hline Urinary incontinence & $37(\% 56.1)$ & $22(\% 33.3)$ & $2(\% 3.0)$ & $5(\% 7.6)$ & $66(\% 100.0)$ \\
\hline İncomplete emptying & $26(\% 39.4)$ & $29(\% 43.9)$ & $4(\% 6.1)$ & $7(\% 10.6)$ & $66(\% 100.0)$ \\
\hline Weak stream of urine & $28(\% 42.4)$ & $30(\% 45.5)$ & $4(\% 6.1)$ & $4(\% 6.1)$ & $66(\% 100.0)$ \\
\hline Frequency & $19(\% 28.8)$ & $29(\% 43.9)$ & $7(\% 10.6)$ & $11(\% 16.7)$ & $66(\% 100.0)$ \\
\hline Nocturia & $6(\% 9.1)$ & $23(\% 34.8)$ & $24(\% 36.4)$ & $13(\% 19.7)$ & $66(\% 100.0)$ \\
\hline \multicolumn{6}{|l|}{ Cardiovascular domain } \\
\hline Lightheaded when standing up & $41(\% 62.1)$ & $23(\% 34.8)$ & $1(\% 1.5)$ & $1(\% 1.5)$ & $66(\% 100.0)$ \\
\hline Lightheaded when standing for sometime & $36(\% 54.5)$ & $29(\% 43.9)$ & $1(\% 1.5)$ & - & $66(\% 100.0)$ \\
\hline Syncope - & $63(\% 95.5)$ & $3(\% 4.5)$ & - & - & $66(\% 100.0)$ \\
\hline \multicolumn{6}{|l|}{ Termoregulatory domain } \\
\hline Hyperhydrosis during the day & $38(\% 57.6)$ & $14(\% 21.2)$ & $10(\% 15.2)$ & $4(\% 6.1)$ & $66(\% 100.0)$ \\
\hline Hyperhydrosis during the night & $39(\% 59.1)$ & $14(\% 21.2)$ & $8(\% 12.1)$ & $5(\% 7.6)$ & $66(\% 100.0)$ \\
\hline Heat intolerance & $44(\% 66.7)$ & $20(\% 30.3)$ & $2(\% 3.0)$ & - & $66(\% 100.0)$ \\
\hline Cold intolerance & $46(\% 69.7)$ & $15(\% 22.7)$ & $4(\% 6.1)$ & $1(\% 1.5)$ & $66(\% 100.0)$ \\
\hline \multicolumn{6}{|l|}{ PMS } \\
\hline Oversensitive to bright light & $43(\% 65.2)$ & $21(\% 31.8)$ & $2(\% 3.0)$ & - & $66(\% 100.0)$ \\
\hline
\end{tabular}

Tablo 4. Sexuel domain.

\begin{tabular}{lllllll}
\hline & Never 0 & Sometimes 1 & Regularly 2 & Often 3 & Not applicable & Total \\
\cline { 2 - 6 } & $\mathrm{n}(\%)$ & $\mathrm{n}(\%)$ & $\mathrm{n}(\%)$ & $\mathrm{n}(\%)$ & $\mathrm{n}(\%)$ & $\mathrm{n}(\%)$ \\
\hline $\begin{array}{l}\text { Erection } \\
\text { problem }\end{array}$ & $17(\% 36.2)$ & $11(\% 23.4)$ & $6(\% 12.8)$ & $9(\% 19.1)$ & $4(\% 8.5)$ & $47(\% 100.0)$ \\
$\begin{array}{l}\text { Ejeculaton } \\
\text { problem }\end{array}$ & $24(\% 51.1)$ & $8(\% 17.0)$ & $4(\% 8.5)$ & $7(\% 14.9)$ & $4(\% 6.1)$ & $47(\% 100.0)$ \\
$\begin{array}{l}\text { Vaginal } \\
\text { lubrication }\end{array}$ & $3(\% 15.8)$ & $1(\% 5.3)$ & - & - & $15(\% 78.9)$ & $19(\% 100.0)$ \\
$\begin{array}{l}\text { Problem } \\
\text { withorgasm }\end{array}$ & $2(\% 10.5)$ & $2(\% 10.5)$ & - & - & $15(\% 78.9)$ & $19(\% 100.0)$ \\
\hline
\end{tabular}

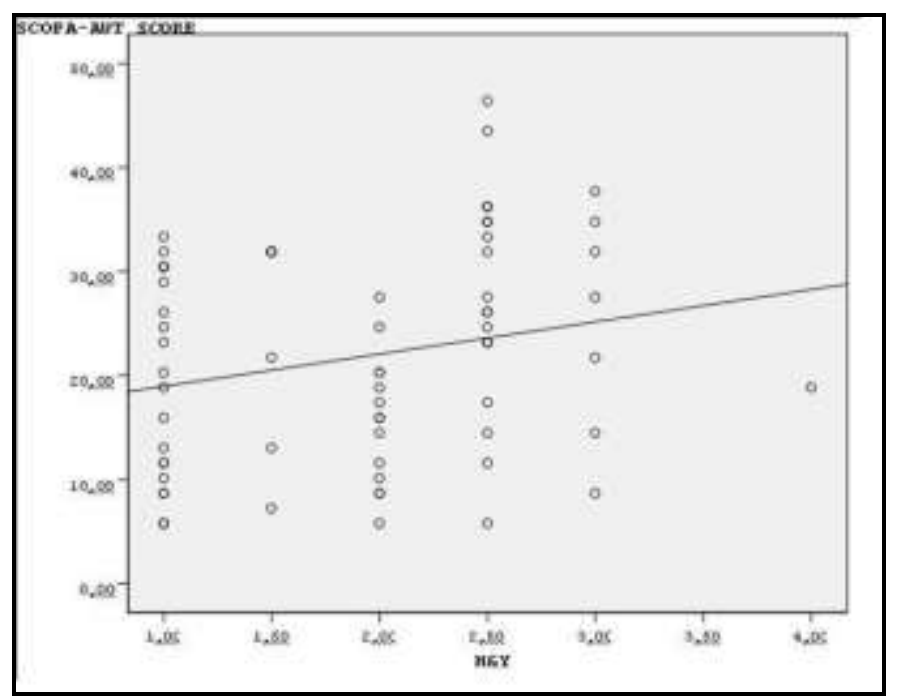

Figure 1. Relation between total SCOPA-AUT and H\&Y. 
Spearman's correlation;

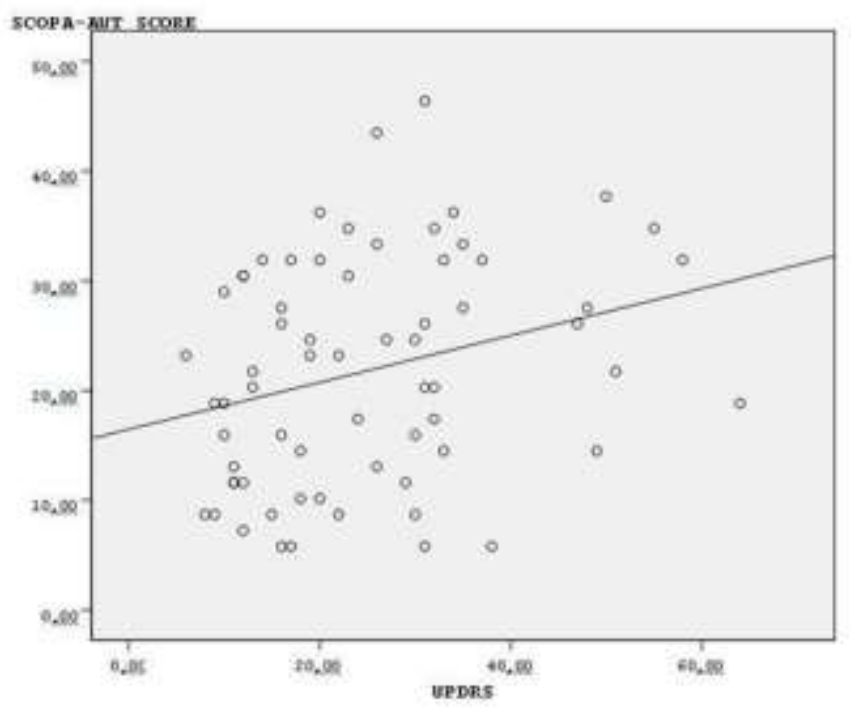

Figure 2. Relation between total SCOPA_AUT and UPDRS.

\section{Discussion}

Autonomic symptoms (AS) occur in almost most patients with PD patients at some stage of their disease and contribute to the disease burden [2, 3]. In this study, AS were evaluated using a reliable and a valid instrument that includes items which considered relevant by patients and specialists [3].

Our study showed that patients with PD experience many problems in urinary, gastroinetsnal, cardiovascular, thermoregulatory, pupillomotor and sexual functions, indicating that virtually no autonomic domain remained unaffected in this disease, as the results were in line with studies that have focused on spesific autonomic impairements in PD $[3,10]$. In compatible with a study that assessed the autonomic dysfunctions in PD with the same questionnaire, the urinary and gastrointestinal symptoms were most frequent and cardivascular and pupillomotor symptoms were less frequent [11]. In view of the often reported cardiac sympathetic denervation, this finding may come as a suprise (unexpected) $[6,12]$. This discrepancy may have emerged bacause of the different applied methods of assessment. As it reported before, we found that total SCOPA-AUT score was increased with longer disease duration and higer disease severity [11]. On the other hand, except gastointestinal domain, others were negatively affected by both disease severity and duration. However, cardivascular domain was only affected by duration of disease. Nevertheless, it has not be forgatten that a few studies reported in contrast to this but it may be due to use different questionnaire [13].

The symptoms that the patients most suffer from were, nocturia, straining for defacation, constipation and frequency of urinating. As it reported before, vajinal lubrication and problems with having an orgasm (women) were answered 'non-applicable' by the patients [12]. Because, patients may hesitate to report these problems, as it may be like in reporting fecal and urinary incontinence. These AS were all embarrassing and have a severe impact on social life. Consequently, increasing clinical awareness is important and may prevent undertreatment of AS in PD. Alltough several therapeutic treatment options for he various areas of AS in PD are available, there is a lack of evidence from randomized trials regarding their efficacy [14]. The high frequency of AS in PD in this study clearly indicates the need for good randomized controlled studies. 
A number of limitations to our study can be identified. First we had no control subjects to make comparision the symptoms with the patients. Second, the medications patients use did not take place in the study altough it has been commonly known that levadopa and dopamin agonists might have produce many severe AS in PD like ortostathic hypotension [14].

In conclusion; the present study is in agreement with previous studies that AS were present in all patients and increased especially with the disease severity. For a better quality of life of the patient, it's important to evaluate the presence of AS and initiate the appropriate treatment.

\section{References}

1. Parkinson J. An essay on the shaking palsy. London: Sherwood, Neely and Jones 1817.

2. Chaudhuri KR, Healy DG, Schapira AH. Non-motor symptoms of Parkinson's dsiease; diagnosis and managemenet. Lancet Neurol 2006: 5: 235-45.

3. Visser M, Marinus J, Stiggelbout AM, van Hilten JJ. Assessment of autonomic dysfunction in Parkinson's disease: The SCOPA-AUT. Mov Disord 2004; 19: 1306-12.

4. Jost WH. Autonomic dysfunction in Parkinson's disease. J Neurol Sci 2003; 24: 32-4.

5. Phia SJ, Rinne JO, Rinne UK, Seppanen A. Autonomic dysfunction in recent onset and advanced Parkinson's disease. Clin Neurol Nerosurg 1988; 90: 221-6.

6. Rajput A, Rodilsky B. Dysautonomia in Parkinsonism: A clinicopathological study. J Neurol Neurosurg Psychiatry 1976; 39: 1092-100.

7. Montastruc j, Senrad J, Rascol O, Rascol A. Autonomic nervous system dysfunction and adrenoreceptor regulation in Parkinson's disease: Clinical and pharmacological consequences. Adv Neurol 1996; 69: 377-81.

8. Jager W, Bethlem J.The distrubition of Lewy bodies in teh central and autonomic nervous system in idiopathic paralysis ajitans. J Neurol Neurosurg Psychiatry 1960; 17: 427-42.

9. Awerbuch G, Sandyk R. Autonomic dysfunction in the early stages of Parkinson's disease. Int J Neurosci 1994; 74: 9-16.

10. Korczyn AD, Goetz C, Kooler W, Poewe W, Sampatio C. Treatment interventions for Parkinson's disease: An evidence based assessment. Lancet 2002; 359: 1589-98.

11. D. Veban, J Marinus, M Visser at all. Patinets-reported autonomic symptoms in Parkinson's dsiease. Neurology 2007; 69: 333-41.

12. Mathias CJ. Cardivascular dysfunction in parkinsonian disorders. Funct Neurol 2001; 16: 257-65.

13. Siddiqui MF, Rast S, Lynn MJ, AUchus AP. Autonomic dysfunction in Parkinson's disease: A comprehensive symptom survey 2002; 8: 277-84.

14. Calne D, Brennan J, Spiers A, Stern G. Hypotension caused by L-dopa. Br Med J 1970; $1:$ 474-5. 